\title{
Shear Strength Prediction of Deep Beams by Softened Truss Model
}

\author{
B.R Niranjan ${ }^{1}$, S.S Patil ${ }^{2}$ \\ ${ }^{1}$ Professor, faculty of engineering-civil,U.V.C.E. Bangalore University Bangalore. India. \\ ${ }^{2}$ Associate Professor, faculty of engineering-Civil, Walchand Institute of Technology. Solapur India.
}

\begin{abstract}
This paper describes the shear behavior of deep beams. The softened truss model theory, which has been successively used for low rise shear walls and torsion, is extended to deep beams. The theory includes effective transverse compressive stress acting on the shear element and softened concrete stress-strain relationship for the concrete behavior. Theoretical shear strengths were compared with experimental result. Examination of the governing equations helps to identify three major factors that affect the shear strength. They are shear span to depth ratio, transverse reinforcement index and longitudinal reinforcement index.
\end{abstract}

Keywords - Deep Beam, Shear strength, Softened truss model, Reinforced Concrete.

\section{Introduction}

Beams with large depths in relation to spans are called deep beams. In IS-456 (2000) Clause 29, a simply supported beam is classified as deep when the ratio of its effective span $\mathrm{L}$ to overall depth $\mathrm{D}$ is less than 2. Continuous beams are considered as deep when the ratio $\mathrm{L} / \mathrm{D}$ is less than 2.5 . The effective span is defined as the centre-to-centre distance between the supports or 1.15 times the clear span whichever is less.

The strength of deep beams has been subject of numerous experimental studies. Several possible modes of failure have been identified from test, but the predominant one is that of shear failure. The shear action in the beam web leads to compression in a diagonal direction and tension in a direction perpendicular. The observation of web crack before failure leads to a theoretical model that assumes the dependency of shear strength on concrete splitting strength. On the other hand, a simple model that recognizes the arch action in deep beam has been proposed to predict web compression failure.

Combining the equilibrium, compatibility and softened stress-strain relationships, a theory was developed which can predict with good accuracy the test results of various types of reinforced concrete structures subjected to shear or torsion. The theory can predict not only the shear and torsion strengths, but also the deformations of a structure throughout its post-cracking loading history. This theory is called the softened truss model theory to emphasis' the importance of the concrete softening phenomenon. It has been successfully used to predict the shear strength of low-rise shear walls, shear strength of framed wall panels, shear transfer strength across an initially un cracked shear plane, torsion strength of beams, and membrane strength of shell elements.

The softening of concrete struts was also incorporated in the prediction of the shear strength of beams by Hagai. For slender beams with shear span to effective-depth ratio between 2.5 and 6 , his truss model predictions agree well with experimental results. However, for beams with shear-span to effective-depth ratio below 2.5 (i.e. the range of deep beams), his predictions underestimate considerably the actual shear strength. For example, for shear span to depth ratio equal to or less than 0.5 , the underestimation may exceed $50 \%$. In this study, it was observed that a correct model for deep beams in shear should include a component of transverse compression in the shear element. With the proper estimation of this transverse compression, the softened truss model theory predicts accurately the shear strength of deep beams.

\section{Theoretical Prediction.}

The prediction of the shear strength was obtained by tracing the load-deformation history numerically and locating the peak shear stress. The accuracy of the theoretical prediction is established by a comparison with experimental data and a sensitivity study.

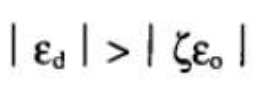$$
\sigma_{\mathrm{d}}=-\zeta f_{\mathrm{c}}^{\prime}\left[1-\left(\frac{\varepsilon_{\mathrm{d}} / \varepsilon_{\mathrm{o}}-\zeta}{2-\zeta}\right)^{2}\right]
$$

Eq 1a 


$$
\left|\varepsilon_{\mathrm{d}}\right| \leq\left|\zeta \varepsilon_{\mathrm{o}}\right| \quad \sigma_{\mathrm{d}}=\zeta f_{\mathrm{c}}^{\prime}\left[2\left(\frac{\varepsilon_{\mathrm{d}}}{\zeta \varepsilon_{\mathrm{o}}}\right)-\left(\frac{\varepsilon_{\mathrm{d}}}{\zeta \varepsilon_{\mathrm{o}}}\right)^{2}\right]
$$

Eq $1 \mathrm{~b} \varepsilon d$, $\varepsilon r$ are average principal strains in $\mathrm{d}$ - and $\mathrm{r}$-directions, respectively (positive for tension). The softening coefficient $\zeta$,

$$
\zeta=\sqrt{\frac{\varepsilon_{\mathrm{d}}}{(1-\mu) \varepsilon_{\mathrm{d}}-\varepsilon_{\mathrm{r}}}}
$$

Eq 2 The factor $\zeta$ is a softening coefficient suggested to be

$$
\varepsilon_{\mathrm{r}} \leq \varepsilon_{\mathrm{cr}} \sigma_{\mathrm{r}}=E_{\mathrm{c}} \varepsilon_{\mathrm{r}}
$$

Eq 3a

$$
\varepsilon_{t}>\varepsilon_{\mathrm{ct}} \quad \sigma_{t}=f_{\mathrm{cr}}\left(1+\sqrt{\frac{\varepsilon_{\mathrm{t}}-\varepsilon_{\mathrm{ct}}}{0.005}}\right)
$$

Eq $3 b$

$$
\begin{array}{cc}
\sigma_{\mathrm{r}}=\frac{\sigma_{\mathrm{d}}\left(K \sin \alpha \cos \alpha-\sin ^{2} \alpha\right)-\rho_{\mathrm{t}} E_{\mathrm{i}} \varepsilon_{\mathrm{i}}}{K \sin \alpha \cos \alpha+\cos ^{2} \alpha} & \varepsilon_{\mathrm{t}}<\varepsilon_{\mathrm{yg}} \\
\sigma_{\mathrm{r}}=\frac{\sigma_{\mathrm{d}}\left(K \sin \alpha \cos \alpha-\sin ^{2} \alpha\right)-\rho_{\mathrm{t}} f_{\mathrm{i}}}{K \sin \alpha \cos \alpha+\cos ^{2} \alpha} & \varepsilon_{\mathrm{i}} \geq \varepsilon_{\mathrm{Iy}}
\end{array}
$$

Eq $4 \mathrm{a} \& 4 \mathrm{~b}$

$$
\begin{array}{ll}
\cos ^{2} \alpha=\frac{\sigma_{\mathrm{t}}+\rho_{\mathrm{l}} E_{\mathrm{s}} \varepsilon_{\mathrm{t}}}{\sigma_{\mathrm{t}}-\sigma_{\mathrm{d}}+\rho_{\mathrm{l}} E_{\mathrm{s}}\left(\varepsilon_{\mathrm{d}}-\varepsilon_{\mathrm{t}}\right)} & \varepsilon_{\mathrm{l}}<\varepsilon_{\mathrm{ly}} \\
\cos ^{2} \alpha=\frac{\sigma_{\mathrm{t}}+\rho_{\mathrm{l}} f_{\mathrm{fy}}}{\sigma_{\mathrm{t}}-\sigma_{\mathrm{d}}} & \varepsilon_{\mathrm{l}} \geq \varepsilon_{\mathrm{tg}}
\end{array}
$$

Eq $5 \mathrm{a} \& 5 \mathrm{~b} \alpha$ is angle of inclination to the longitudinal steel bars.

$$
\begin{aligned}
& p=K v \\
& K=2 d_{v} / h \quad 0<a / h \leq 0.5 \\
& K=\frac{d_{\mathrm{v}}}{h}\left[\frac{4}{3}\left(\frac{h}{a}-\frac{1}{2}\right)\right] \quad 0.5<a / h \leq 2 \\
& K=0 \quad a / h>2
\end{aligned}
$$


The five Eqns (1a or b), (2), (3a or b), (4a or b) and (5a or b) include six unknowns: $\sigma \mathrm{d}, \sigma \mathrm{r}, \varepsilon \mathrm{d}, \mathrm{cr}, \alpha$, and $\zeta$. When one unknown is given, the other five can be solved.

From the above theoretical equations, it was observed that the most important factors in the shear strength of deep beams are the shear-span to height ratio, the amount of longitudinal reinforcement, and the amount of transverse reinforcement. A parametric study was carried out to determine the influence of the three factors on the shear strength of deep beams.

In this study the softened truss model theory was applied to predict the shear behavior of deep beams. By introducing an effective transverse compression in the beam web, the theory can predict accurately the shear strength of deep beams with vertical web reinforcement. The shear strength was calculated by using softened truss model and the results were tabulated in table 1 and table 2.

TABLE 1: SHEAR STRENGTH CALCULATION USING SOFTENED TRUSS MODEL

\begin{tabular}{|c|c|c|c|c|c|c|c|c|c|}
\hline $\begin{array}{c}\text { BEAM } \\
\text { Number }\end{array}$ & $\rho_{\mathrm{l}} \%$ & $\rho_{\mathrm{t}}$ & $\begin{array}{c}f_{l y} \\
\mathrm{~N} / \mathrm{mm}\end{array}$ & $f_{\text {ty } / \mathrm{mm}}{ }^{2}$ & $\begin{array}{c}\mathrm{E}_{\mathrm{s}} \\
\mathrm{N} / \mathrm{mm}^{2}\end{array}$ & $\begin{array}{c}f_{c}^{\prime} \\
N / m m\end{array}$ & $\begin{array}{c}a \\
m m\end{array}$ & $\begin{array}{c}h \\
m m\end{array}$ & $a / h$ \\
\hline 1 & 0.00899 & 0.0029 & 435 & 217.5 & 200000 & 16 & 175 & 325 & 0.538 \\
\hline 2 & 0.00899 & 0.0029 & 435 & 217.5 & 200000 & 16 & 200 & 325 & 0.615 \\
\hline 3 & 0.00899 & 0.0029 & 435 & 217.5 & 200000 & 16 & 225 & 325 & 0.692 \\
\hline 4 & 0.00899 & 0.00343 & 435 & 217.5 & 200000 & 16 & 200 & 325 & 0.615 \\
\hline 5 & 0.00899 & 0.00419 & 435 & 217.5 & 200000 & 16 & 200 & 325 & 0.615 \\
\hline 6 & 0.00899 & 0.00471 & 435 & 217.5 & 200000 & 16 & 200 & 325 & 0.615 \\
\hline 7 & 0.0104 & 0.0029 & 435 & 217.5 & 200000 & 16 & 200 & 325 & 0.615 \\
\hline 8 & 0.012 & 0.0029 & 435 & 217.5 & 200000 & 16 & 200 & 325 & 0.615 \\
\hline 9 & 0.0137 & 0.0029 & 435 & 217.5 & 200000 & 16 & 200 & 325 & 0.615 \\
\hline
\end{tabular}

TABLE 2: SHEAR STRENGTH CALCULATION USING SOFTENED TRUSS MODEL

\begin{tabular}{|c|c|c|c|c|c|c|c|c|c|}
\hline $\begin{array}{c}\text { BEAM } \\
\text { NUME } \\
\mathrm{R}\end{array}$ & $\begin{array}{c}d_{v} \\
m m\end{array}$ & $\begin{array}{c}b \\
m m\end{array}$ & $\begin{array}{c}\mathrm{V}_{\operatorname{maxt}} \\
\mathrm{kN}\end{array}$ & $\lambda$ & $\begin{array}{c}\alpha, \\
\mathrm{deg}\end{array}$ & $\gamma_{\mathrm{lt}}$ & $v / f_{c}^{\prime}$ & $\mathrm{V}_{\operatorname{maxc}}$ & $\begin{array}{c}\mathrm{kN} \\
\mathrm{V}_{\operatorname{maxc}} / \\
\mathrm{V}_{\operatorname{maxt}}\end{array}$ \\
\hline 1 & 270 & 150 & 270 & 1.32 & 59.76 & -0.00321 & 0.373 & 241.543 & 0.895 \\
\hline 3 & 270 & 150 & 260 & 1.47 & 56.21 & -0.00394 & 0.357 & 231.337 & 0.889 \\
\hline & 270 & 150 & 256 & 1.59 & 53.24 & -0.00461 & 0.341 & 221.109 & 0.864 \\
\hline 5 & 270 & 150 & 8 & 1.47 & 56.08 & -0.00398 & 0.356 & 230.979 & 0.886 \\
\hline 5 & 270 & 150 & 262 & 1.48 & 55.97 & -0.00396 & 0.356 & 230.52 & 0.879 \\
\hline 6 & 270 & 150 & 2 & 1.48 & 55.86 & -0.004 & 0.355 & 230.221 & 0.822 \\
\hline 8 & 270 & 150 & 280 & 1.43 & 56.09 & -0.00379 & 0.366 & 237.248 & 0.847 \\
\hline 9 & 270 & 150 & 316 & 1.4 & 55.99 & -0.00366 & 0.375 & 242.963 & 0.769 \\
\hline
\end{tabular}

$\rho_{\mathrm{l}=\%}$ Longitudinal Reinforcement.

$\rho_{\mathrm{t}=\%}$ Transverse Reinforcement.

$f_{l y}=$ Yield stress of Longitudinal Reinforcement.

$f_{t y}=$ Yield stress of Transverse Reinforcement.

$\mathrm{E}_{\mathrm{s}}=$ Young's Modules of steel.

$f_{c}^{\prime}=$ Characteristics strength of Concrete.

$a=$ Shear span.

$h=$ height.

$d v=$ Effective depth of shear element.

$\Lambda=$ Coefficient for softening effect.

$\alpha=$ Angle of inclination of the $\mathrm{d}$-axis with respect to 1-axis.

$y l t=$ Average shear strain in the $1-t$ coordinate.

\section{Parametric Study}

Parametric studies were carried out to investigate the variation of shear strength with respect to the important factors involved and are tabulated in table1.. A close examination of the governing equation reveals that the normalized shear strength $v_{\mathrm{n}} / f_{c}^{\prime}$ is mainly affected by the two dimensionless parameters $\rho_{\mathrm{t}} f_{t y} / f_{c}^{\prime}$ and $\rho_{\mathrm{l}}$ $f_{l y} / f_{c}^{\prime}$. Together with the parameters $\mathrm{a} / \mathrm{h}$ inherent in $\mathrm{K}$, these three parameters represent the amount of 
longitudinal reinforcement, the amount of transverse reinforcement, and the geometry of the beam, respectively. The first two parameters may be called the longitudinal reinforcement index and the transverse reinforcement index.

Following are three parameters.

1) Shear span to height ratio

2) Longitudinal reinforcement

3) Transverse reinforcement

1) Shear Span to Height Ratio:

The figure shows the variation of the maximum shear strength with respect to the shear span to height ratio. For transverse reinforcement, the minimum percentage is 0.0025 based on the ACI Building Code. For longitudinal reinforcement, the minimum is 0.006 , which is approximately the sum of minimum web steel ratio and the minimum flexural steel ratio.

Following figure1. indicates that the shear strength ratio $v_{\mathrm{n}} / f_{c}^{\prime}$ generally decrease with increasing $a / h$ ratio. The rate of decrease large with lower ratio of transverse reinforcement.

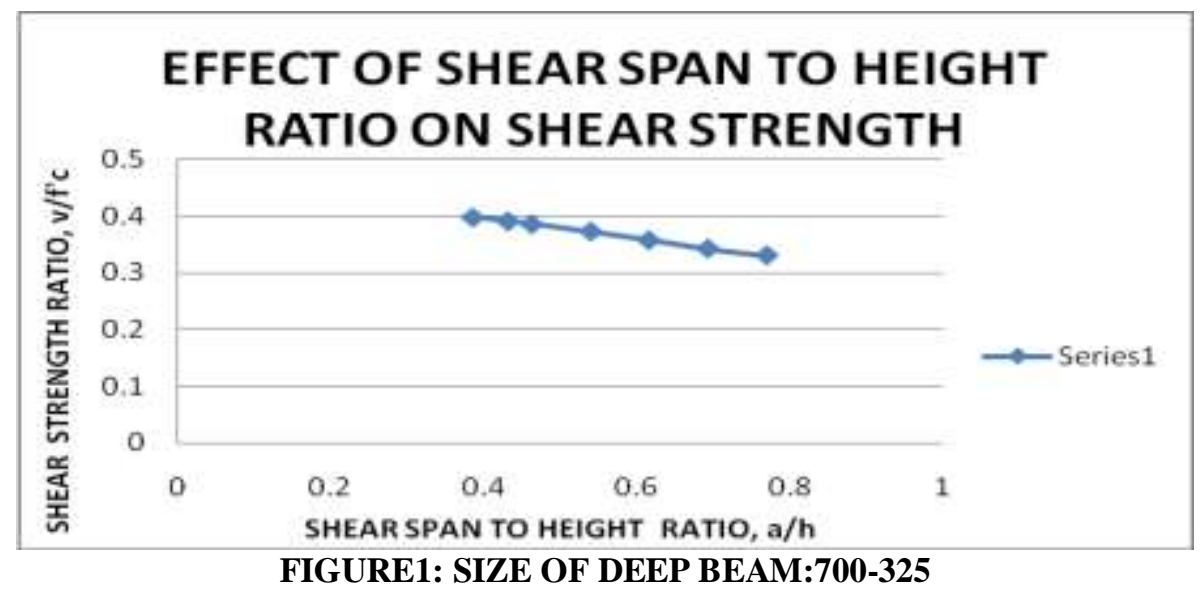

\section{2) Longitudinal Reinforcement Index:}

The effect of the longitudinal reinforcement index $\rho_{\mathrm{l}} f_{l y} / f_{c}^{\prime}$ on the shear strength ratio $v_{\mathrm{n}} / f_{c}^{\prime}$ is shown in figure2. same shear span to height ratio $a / h$ and transverse reinforcement indices $\rho_{\mathrm{t}} f_{t y} / f_{c}^{\prime}$. Following figure shows that the shear strength ratio increases with increase of longitudinal reinforcement index. This means that the longitudinal steel is effective for $a / h$ ratios from 0.5 to 2 and with transverse reinforcement indices from 0.05 to 0.55 . The effectiveness is relatively is large when the longitudinal reinforcement index varies from 0.1 to 0.3 but gradually smaller at higher range.

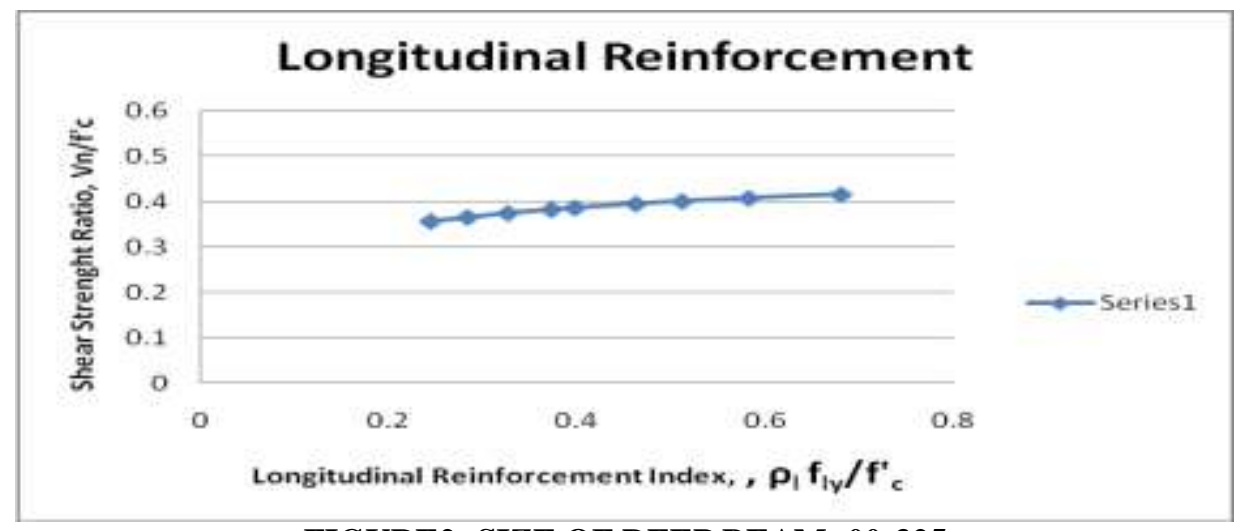

FIGURE2: SIZE OF DEEP BEAM: 00-325

\section{3) Transverse Reinforcement Index:}

The variation of shear strength ratio as a function of transverse reinforcement index is shown in figure 3 . It is shown that the shear strength ratio decreases with increase of transverse reinforcement index. This is because under large effective transverse compression, i.e. small a/h ratio, more transverse reinforcement leads to relative less compressive strain $\varepsilon_{\mathrm{d}}$ and this is turn leads to more softening of the concrete. 
In the view of theory, it seems reasonable to state that the effectiveness of transverse reinforcement decreases when $a / h$ decreases from 2 to 0.5 an increase of transverse reinforcement beyond the ACI Code minimum requirement, is not effective in increasing the shear strength of deep beams.

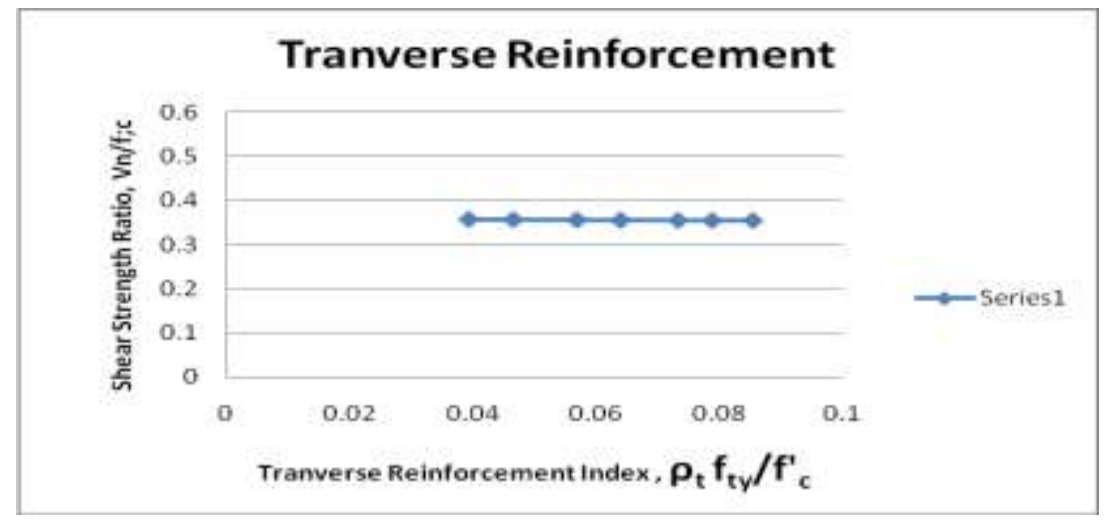

FIGURE3: SIZE OF DEEP BEAM:700-325.

IV. Experimental Results.

Several deep beams were designed for two point loads of $50 \mathrm{kN}$ each, cast having size $700 \mathrm{~mm}$ length, $150 \mathrm{~mm}$ width and $325 \mathrm{mmdepth}$ were tested for various shear spans in heavy structures laboratory. The results were tabulated in table3.

\begin{tabular}{|c|c|c|c|c|c|c|c|c|c|c|}
\hline \multirow{2}{*}{\multicolumn{2}{|c|}{ Beam No. }} & & & & KES & & & & & \\
\hline & & B1 & B2 & B3 & B4 & B5 & B6 & B7 & B8 & B9 \\
\hline \multicolumn{2}{|c|}{ Shear span $(\mathrm{mm})$} & 175 & 200 & 225 & 200 & 200 & 200 & 200 & 200 & 200 \\
\hline \multicolumn{2}{|c|}{$\begin{array}{l}\text { Shear span to depth } \\
\text { ratio }\end{array}$} & 0.54 & 0.62 & 0.69 & 0.62 & 0.57 & 0.62 & 0.62 & 0.62 & 0.62 \\
\hline \multirow[t]{2}{*}{$\begin{array}{l}\text { Reinforce } \\
\text { ment } \\
\text { provided } \\
\text { (No.of } \\
\text { bars) }\end{array}$} & $\begin{array}{l}\text { Flexure } \\
\text { steel } \\
\text { Required } \\
\text { in } \mathrm{mm}^{2}\end{array}$ & 121.79 & 139.12 & 156.42 & 139.12 & 139.12 & 139.12 & 139.12 & 139.12 & 139.12 \\
\hline & $\begin{array}{l}\text { Flexure } \\
\text { steel } \\
\text { Provided } \\
\text { i) } 8 \mathrm{~mm} \\
\Phi\end{array}$ & $\begin{array}{c}3 \\
150.79\end{array}$ & $\begin{array}{c}3 \\
150.79\end{array}$ & 201.06 & 150.79 & 150.79 & 150.79 & 150.79 & $\begin{array}{c}3 \\
150.79\end{array}$ & $\begin{array}{c}3 \\
150.79\end{array}$ \\
\hline \multirow{2}{*}{$\begin{array}{l}\text { Load at } \\
\text { first crack }\end{array}$} & Total & $160 \mathrm{kN}$ & $212 \mathrm{kN}$ & $164 \mathrm{kN}$ & $172 \mathrm{kN}$ & $160 \mathrm{kN}$ & $184 \mathrm{kN}$ & $160 \mathrm{kN}$ & $212 \mathrm{kN}$ & $184 \mathrm{kN}$ \\
\hline & $\begin{array}{l}\text { Each } \\
\text { Point load }\end{array}$ & $80 \mathrm{kN}$ & $106 \mathrm{kN}$ & $82 \mathrm{kN}$ & $86 \mathrm{kN}$ & $80 \mathrm{kN}$ & $92 \mathrm{kN}$ & $80 \mathrm{kN}$ & $106 \mathrm{kN}$ & $92 \mathrm{kN}$ \\
\hline \multirow[t]{2}{*}{$\begin{array}{l}\text { Failure } \\
\text { Load }\end{array}$} & Total & $270 \mathrm{kN}$ & $260 \mathrm{kN}$ & $256 \mathrm{kN}$ & $\begin{array}{c}260.8 \mathrm{k} \\
\mathrm{N}\end{array}$ & $262 \mathrm{kN}$ & $\begin{array}{l}280.2 \mathrm{k} \\
\mathrm{N}\end{array}$ & $280 \mathrm{kN}$ & $316 \mathrm{kN}$ & $332 \mathrm{kN}$ \\
\hline & $\begin{array}{l}\text { Each } \\
\text { Point load }\end{array}$ & $135 \mathrm{kN}$ & $130 \mathrm{kN}$ & $128 \mathrm{kN}$ & $\begin{array}{c}130.4 \mathrm{k} \\
\mathrm{N}\end{array}$ & $131 \mathrm{kN}$ & $\begin{array}{l}140.1 \mathrm{k} \\
\mathrm{N}\end{array}$ & $140 \mathrm{kN}$ & $158 \mathrm{kN}$ & $166 \mathrm{kN}$ \\
\hline \multirow{2}{*}{$\begin{array}{l}\text { Deflectio } \\
\mathrm{n} \text { at } \\
\text { failure }\end{array}$} & Total & $\begin{array}{l}2.4 \mathrm{~m} \\
\mathrm{~m}\end{array}$ & $\begin{array}{l}2.2 \mathrm{~m} \\
\mathrm{~m}\end{array}$ & $\begin{array}{l}2.3 \mathrm{~m} \\
\mathrm{~m}\end{array}$ & $\begin{array}{c}2.6 \mathrm{~m} \\
\mathrm{~m}\end{array}$ & $\begin{array}{l}2.4 \mathrm{~m} \\
\mathrm{~m}\end{array}$ & $\begin{array}{l}2.4 \mathrm{~m} \\
\mathrm{~m}\end{array}$ & $\begin{array}{l}2.5 \mathrm{~m} \\
\mathrm{~m}\end{array}$ & 2. $\mathrm{mm}$ & $2 \mathrm{~mm}$ \\
\hline & $\begin{array}{l}\text { Permissib } \\
\text { le } \\
\text { deflection }\end{array}$ & $\begin{array}{l}2.4 \mathrm{~m} \\
\mathrm{~m}\end{array}$ & $\begin{array}{l}2.4 \mathrm{~m} \\
\mathrm{~m}\end{array}$ & $\begin{array}{l}2.4 \mathrm{~m} \\
\mathrm{~m}\end{array}$ & $\begin{array}{l}2.4 \mathrm{~m} \\
\mathrm{~m}\end{array}$ & $\begin{array}{l}2.4 \mathrm{~m} \\
\mathrm{~m}\end{array}$ & $\begin{array}{l}2.4 \mathrm{~m} \\
\mathrm{~m}\end{array}$ & $\begin{array}{l}2.4 \mathrm{~m} \\
\mathrm{~m}\end{array}$ & $\begin{array}{l}2.4 \\
\mathrm{~mm}\end{array}$ & $\begin{array}{l}2.4 \mathrm{~m} \\
\mathrm{~m}\end{array}$ \\
\hline
\end{tabular}




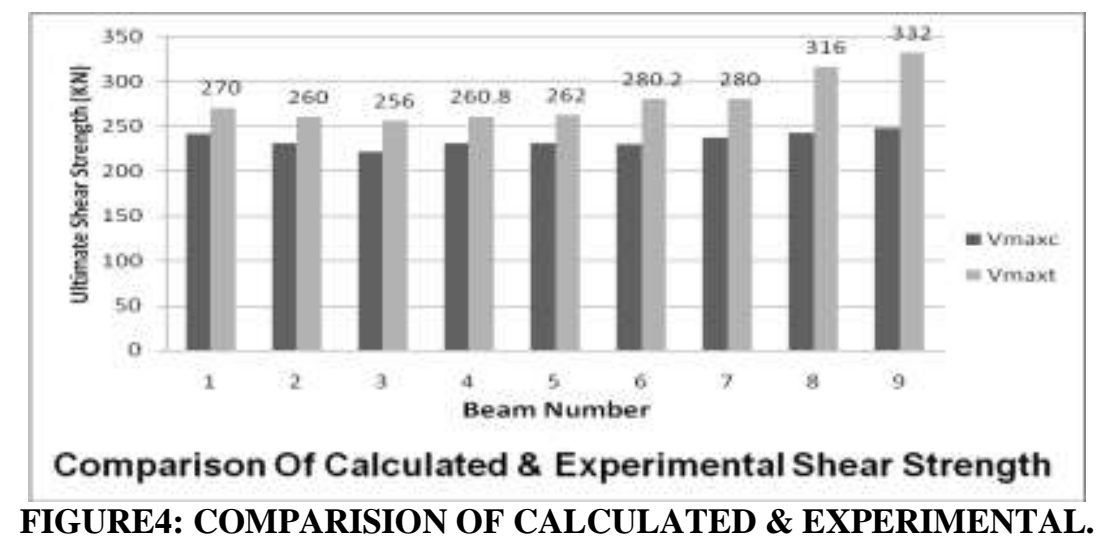

\section{Conclusion.}

1. Failure of deep beams was mainly due to diagonal cracking and it was along the lines joining the loading points and supports.

2. The strength of beams with $250 \mathrm{~mm}$ shear span is about $5 \%$ less than that of $200 \mathrm{~mm}$ shear span. It is clear from these results that the strength of deep beam is inversely proportional to the shear span for the constant depth of the beam.

3. By adding an effective transverse compression stress to the web shear element of a deep beam, the softened truss model theory is shown to predict with reasonable accuracy the shear strength of simply supported beams with transverse web reinforcement and having shear span to height ratio between 0.33 to 2 .

4. Three non dimensional zed parameters are identified as having major effect on the maximum shear strength of deep beams. They are the shear span to depth ratio, longitudinal reinforcement index and transverse reinforcement index. The extent of the effect varies according to the range of magnitude of these parameters.

5. For small a/h ratio (below 0.5 ), the present theory predicts that transverse reinforcement is ineffective in increasing the shear strength.

[1] F. K. Kong, Reinforced Concrete Deep Beams.

\section{References}

[2] Mr.Varghese and Mr.Krishnamoorthy, (1966), Strength and Behaviour of Deep Reinforced Concrete Beams, Indian Concrete Journal, 104-108.

[3] Varghese, Advanced Design of Reinforced Concrete Structures.

[4] Park \& Pauly, Reinforced Concrete Structures

[5] Peter Marti,(1985), Basic Tools of Reinforced Concrete Beam Design, ACI journal, Title no. 82-4

[6] N.Krishna Raju, Advanced Reinforced Concrete Design.CBS Publications

[7] ACI 318-2002 Building Code and Commentary.

[8] American Concrete Institute Committee 318. (1989) Building Code Requirements for Reinforced Concrete. ACI 318-89, American Concrete Institute, Detroit

[9] Han, K.J. and Mau, S.T.(1988) Membrane behaviour of r/c shell element and limits on the reinforcement J. Struct. Mechcs, Am. Soc. Civ. Engrs 114 No. 2: 425.

[10] Thomas T.C. Hsu "Softened Truss Model Theory for Shear and Torsion" ACI Structural Journal , Nov-Dec 1988,pp624-635

[11] Collins, M. (1973) Torque-twist characteristics of reinforced concrete beams, In Inelasticity andNon-Linearity in Structural Concrete. University of Waterloo Press, Waterloo Ontario: 211

[12] Smith, K.N. and Vansiotis, A.S. (1982) Shear strength of deep beams, J. Am. Concr. Inst. 79 No. 3: 201.

[13] Vecchio, F. and Collins, M.P. (1981) Stress-strain characteristics of reinforced concrete in pureshear. IABSE Colloquium, Advanced Mechanics of Reinforced Concrete, Delft, Final report: 211

[14] Hsu, T.T.C. and Mo, Y.L. (1985a) Softening of concrete in torsional members - theory and tests, J. Am. Concr. Inst. 82 No. 3: 290.

[15] Hsu, T.T.C. and Mo, Y.L (1985b) Softening of concrete in torsional members-design recommendations, J. Am. Concr. Ins. 82 No. 4: 443 . 